\title{
The Development of a Genetic Database to Identify Olive Cultivars
}

\author{
Jenny R. Guerin \\ Department of Horticulture, Viticulture and Oenology, University of Adelaide, Waite Campus, Private \\ Mail Bag 1, GLEN OSMOND SA 5064, Australia
}

\author{
Susan M. Sweeney \\ Primary Industries and Resources South Australia (PIRSA) Rural Solutions, Plant Research Centre, \\ Waite Campus, GPO Box 397, SA 5001, Australia \\ Graham G. Collins and Margaret Sedgley ${ }^{1}$ \\ Department of Horticulture, Viticulture and Oenology, University of Adelaide, Waite Campus, Private \\ Mail Bag 1, GLEN OSMOND SA 5064, Australia
}

\begin{abstract}
ADDITIONAL INDEX WORDS. RAPD-PCR, DNA fingerprinting Olea europaea
Abstract. The National Olive Variety Assessment (NOVA) collection, established at the Roseworthy Campus of the University of Adelaide, contains six replicate trees of 100 olive (Olea europaea L.) accessions grown in the same environment. The DNA fingerprints of these accessions were compared, using randomly amplified polymorphic DNA (RAPD), to those of a number of cultivars obtained from international collections. A total of 86 uniquely named accessions in the NOVA collection resulted in 58 different genotypes. Different names were synonyms for the same genotype, and homonyms were also found where accessions with the same name had different DNA fingerprints. A rapid and efficient protocol was developed to identify unknown olive genotypes using a two-stage process. Data from DNA fingerprints were added to a matrix already containing binary data from recognized standard cultivars. The estimated probability of any given RAPD profile randomly occurring at this stage ranged between $6 \times 10^{-4}$ and $2 \times 10^{-8}$. In the second stage, the approximate identity of the unknown genotype, revealed by the resulting dendrogram, was confirmed by comparing it with appropriate standards under identical conditions of DNA amplification and band separation. The data collected in this report form the basis of a genetic database that can be used for the identification of olive samples.
\end{abstract}

Olives (Olea europaea L.) are predominantly allogamous, which leads to high levels of heterozygosity and DNA polymorphism among individuals (Angiolillo et al., 1999; Rallo et al., 2000). To avoid segregation of positive characters through sexual reproduction, cultivars are clonally propagated so that, barring somatic mutation, propagules will be genetically identical to the mother tree. The use of DNA markers is a practical method of cultivar identification given the levels of DNA polymorphism among cultivars and the genetically stable methods of propagation. The random amplified polymorophic DNA (RAPD) technique has previously been used to successfully distinguish between olive cultivars (Belaj et al., 2001; Besnard et al., 2001a; Fabbri et al., 1995; Mekuria et al., 1999; Sanz-Cortés et al., 2001; Weisman et al., 1998). A small number of RAPD bands have been shown to be effective in discriminating among olive cultivars with a low rate of confusion (Besnard et al., 2001b).

Olives are not native to Australia, and much of the planting material being used is sourced from trees that were imported from Europe over 100 years ago. Trees are often selected from abandoned groves or collections where the records are incomplete, unreliable or no longer exist, leading to confusion about the identity of individual accessions (Burr, 1998).

Received for publication 2 May 2002. Accepted for publication 26 Aug. 2002. The authors thank all those who provided and collected the olive leaves used in this study. Special thanks are given to Michael Burr, Shimon Lavee, and Gerry Davies, whose advice and support were instrumental in establishing this collection. NOVA is funded by the Rural Industries Research and Development Corporation (RIRDC), Primary Industries and Resources South Australia (PIRSA), Agrolive Pty Ltd, and the Australian Olive Association (AOA). The project is also supported by the state governments of South Australia, Western Australia, New South Wales, Victoria, and Tasmania, and the Australian Research Council. ${ }^{1}$ Corresponding author: e-mail margaret.sedgley@adelaide.edu.au.
The National Olive Variety Assessment (NOVA) collection, located at the Roseworthy Campus of the University of Adelaide, was established by PIRSA in 1998 to evaluate the physiological and chemical characteristics of all known olive cultivars in Australia, under the same environmental conditions. This paper reports on the verification of the cultivar names of the trees in the NOVA collection by comparing genetic similarities with standards obtained from trees in a number of international and Australian collections. In addition, a method is described for verifying cultivar identities using a database of DNA fingerprints.

\section{Materials and Methods}

Plant Material. The NOVA trial consists of six replicate trees of 100 accessions sourced from nurseries and collections across Australia. Eighty-seven of these were regarded as different olive cultivars. Thirteen of the accessions had the same name as others in the trial but were of different provenances or planted at a different time.

Olive leaves for DNA fingerprinting were obtained from the following collections, with the codes used in this study shown in parentheses: NOVA trial, University of Adelaide Roseworthy Campus (NOVA); The Olive World Collection, Centro de Investigacion y Desarollo Agrario, Cordoba, Spain (Spain); The Volcani Centre, Bet-Dagan, Israel (Israel); CORIPROL, Pescia, Italy (Italy1); Consiglio Nationale delle Ricerche, Instituto di Ricerca Sulla Olivicultura, Perugia Italy (Italy2); Foundation Plant Material Service, University of California, Davis, California, United States (United States and Mexico); Subtropical Plants and Olive Trees Institute of Chania Agrokipio, Chania, Greece (Greece); JouveRacamond Nursery, Avignon, France (France); Charles Sturt 
University Olive Collection (Australia) and from a number of nurseries and groves within Australia (Aus).

Fresh leaves were packed for transport as described by Mekuria et al. (1999) and on receipt, were frozen in liquid nitrogen and stored at $-80{ }^{\circ} \mathrm{C}$ until extraction.

DNA EXTRACTION. DNA was extracted from each of the replicate NOVA trees and standard cultivars using a modification of the method described by Mekuria et al. (1999). Leaf material (200 mg) was ground to a fine powder in liquid nitrogen, extracted with 500 $\mu \mathrm{L}$ of extraction buffer [3\% (w/v) cetyltrimethyl ammonium bromide; $1.4 \mathrm{~m} \mathrm{NaCl}$; 0.1 м EDTA pH 8.0; 1 м Tris $\mathrm{HCl} \mathrm{pH} \mathrm{8.0],} \mathrm{and}$ incubated at $60^{\circ} \mathrm{C}$ for $30 \mathrm{~min}$, with occasional gentle mixing.

The sample was then mixed with $500 \mu \mathrm{L}$ of 24 chloroform : 1 isoamyl alcohol for $10 \mathrm{~min}$ at room temperature before centrifugation at $8000 \mathrm{rpm}$ for $20 \mathrm{~min}$. The aqueous layer was precipitated with $2 / 3 \mathrm{vol}$ of cold isopropanol, and the DNA spooled with a fine glass rod and washed at least three times in 1-mL aliquots of wash buffer (76\% ethanol; $10 \mathrm{~mm} \mathrm{NH}_{4}$ acetate).

The DNA was dissolved in $100 \mu \mathrm{L}$ of TE buffer and RNA was removed by adding $10 \mu \mathrm{g}$ RNase A (DNase-free) (AMRESCO Solon, United States) and incubating at $37^{\circ} \mathrm{C}$ for $30 \mathrm{~min}$. Residual proteins were removed by adding $\mathrm{NH}_{4}$ acetate to a final concentration of $2.5 \mathrm{M}$, incubating on ice for $20 \mathrm{~min}$ (Crouse and Amorese, 1987), and centrifuging at 14,000 rpm for $20 \mathrm{~min}$. DNA was recovered after precipitation with cold ethanol, and dissolved in 100 $\mu \mathrm{L}$ TE buffer.

The purity of the DNA was evaluated by measuring the absorbances at 230, 260, and $280 \mathrm{~nm}$, and calculating the ratios of the absorbance at 260:280 and 260:230. DNA samples used for cultivar identification had absorbance ratios greater than 1.8.

RAPD ANALYSIS. RAPD bands were generated using PCR in a volume of $20 \mu \mathrm{L}$ containing $40 \mathrm{ng}$ genomic DNA, $1.5 \mathrm{~mm} \mathrm{MgCl}$, $0.3 \mu \mathrm{M} 10$-mer oligodeoxynucleotide primer, $200 \mu \mathrm{M}$ each of dGTP, dATP, dTTP, dCTP, $1 \times$ PCR Buffer $(10 \mathrm{~mm}$ Tris HCl pH 8.3; $50 \mathrm{~mm}$ $\mathrm{KCl} ; 0.001 \%(\mathrm{w} / \mathrm{v})$ gelatine) and 0.6 units Taq DNA polymerase (Life Technologies, United States) and overlaid with paraffin oil. Negative controls, with genomic DNA omitted, were run with every PCR to check for DNA contamination. The PCR program was as reported by Collins and Symons (1993). PCR reactions were carried out, in duplicate, with the six random 10-mer primers used by Mekuria et al. (1999): GC01 5'-CAGGCCCTTC; GC05 5'AGGGGTCTTG; GC18 5'-AGGTGACCGT; GC20 5'-GTTGCGATCC; OPZ11 5'-CTCAGTCGCA; OPZ13 5'-GACTAAGCCC.

Amplified fragments were separated by electrophoresis at $200 \mathrm{~V}$ on $1.75 \%(w / v)$ agarose gels in $1 \times$ TBE buffer (Sambrook et al., 1989), and visualized under UV light after staining with 400 $\mu \mathrm{g} \cdot \mathrm{L}^{-1}$ ethidium bromide.

VERIFICATION OF REPLICATE TREES IN THE NOVA COLLECTION. TO confirm genetic consistency within the six replicate trees of each accession in the NOVA collection, the PCR products obtained from a bulked DNA sample, containing $8 \mathrm{ng}$ of genomic DNA from each of five replicate trees (total $40 \mathrm{ng}$ ), were compared on the same gel with those obtained from the DNA (40 ng) from the remaining replicate of that cultivar. When differences in the DNA fingerprints between the two samples were detected, separate PCR reactions were carried out on the five individual trees making up the bulked DNA sample in order to identify anomalous samples.

COMPARISON OF ACCESSIONS IN THE NOVA COLLECTION WITH STANDARD CULTIVARS. Cultivars from the NOVA collection were run on the same gel as standards sourced from other collections. Each sample of DNA was tested in duplicate with six 10-mer primers, and only bands that were reproducible were scored. If necessary, a third PCR reaction was carried out to confirm the presence of some bands. The presence and absence of bands on the gels was recorded using Gelpro 32 (Media Cybernetics, Maryland, United States), and translated to a binary matrix by allocating 1 or 0 for the presence or absence of bands, respectively. Genetic similarities among all pairs of individuals were estimated using the simple matching coefficient (Sokal and Michener, 1958) as described in Apostol et al. (1993). Cluster analysis was performed on the estimated similarities using the unweighted pair group method with arithmetic average(UPGMA) and the SAHN algorithm, and the resulting clusters were expressed as a dendrogram using NTSYS-pc (Exeter Software v.2.0).

The probability that an individual taken at random has any given RAPD profile in the subset of unique olive cultivars was calculated as the product of the frequencies of bands, where the frequency of presence $(p)$ and absence (1-p) of bands were taken into account (Besnard et al., 2001b).

\section{Results}

DEVELOPMENT OF A PROCEDURE FOR CULTIVAR IDENTIFICATION. It was required to develop a rapid and efficient means of identifying accessions by comparison with known standards, and this objective

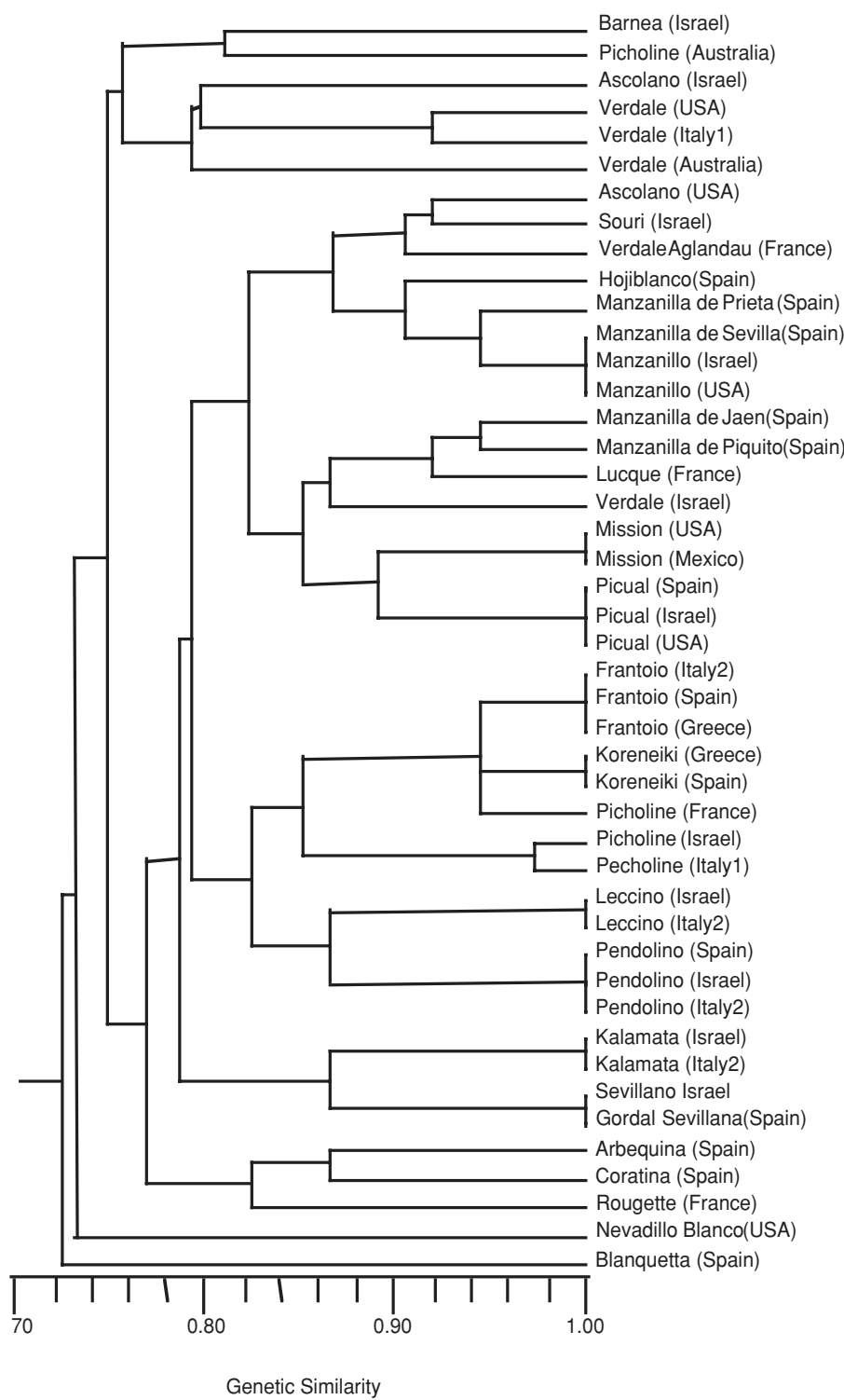

Fig. 1. Dendrogram of reference standards tested from international collections. 
was achieved with a two-stage process. The first stage was to construct a dendrogram that had acceptable discrimination power, whereby the binary data for a new DNA fingerprint could be added to the existing matrix for the standards, and an approximate identity for the new accession could be determined from the dendrogram. This approximate identity would then be confirmed by comparing the DNA fingerprint of the new accession with those of the standards on the same gel.

The data for each primer were removed sequentially from the binary matrix of the standards until a satisfactory discrimination was achieved for stage 1 without unduly compromising the accuracy of the identification. This occurred with 26 polymorphic bands from the primers GC01, GC05, OPZ11, and GC18.

GENETIC VARIABILITY BETWEEN AND WITHIN THE CULTIVAR STANDARDS. To ensure the reliability of the standards used, DNA fingerprints were obtained from more than one international source (Fig. 1). Accessions of the same cultivar were run on the same gel and 96 bands generated from six primers were compared. Different accessions, derived from more than one international source, of Picual, Kalamata, Frantoio, Mission, Pendolino, Leccino, Koroneiki,
Sevillano, and Manzanillo had the same DNA fingerprints. Several Australian accessions of Manzanillo were found to be genetically identical to another obtained from the United States (Mekuria et al., 1999), and also to Manzanilla de Sevilla from the Germplasm Bank of the Centro de Investigación y Formación Agraria “Alameda del Obispo" in Cordoba, Spain. The Cordoba accessions, Manzanilla de Sevilla, Manzanilla de Prieta, Manzanilla de Jaen, and Manzanilla de Piquito are all genetically distinct (Fig. 1).

Three of the standards, Verdale, Picholine, and Ascolano varied among samples obtained from different collections. This was found for five accessions of Verdale sourced from France, Italy, Israel, United States, and Australia, four accessions of Picholine from France, Italy, Israel, and Australia, and two accessions of Ascolano from Israel and the United States. Variation among accessions of Verdale has been described previously (Mekuria et al., 1999). In the absence of a genetic consensus for each of these cultivars, both the cultivar name and source are quoted when these were used as reference cultivars.

IDENTIFICATION OF THE NOVA CULTIVARs. Table 1 shows the

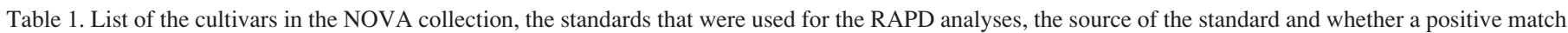
was identified.

\begin{tabular}{|c|c|c|c|}
\hline Varietal name & Standard name & Source $^{z}$ & Match \\
\hline Amelon & Amelon & Australia & No \\
\hline Arbequina 1 & Arbequina & Spain & Yes \\
\hline Arbequina 2 & Arbequina & Spain & Yes \\
\hline Areccuzo & $\mathrm{NA}^{\mathrm{y}}$ & --- & --- \\
\hline Ascolano & Ascolano & United States & Yes \\
\hline Atro Rubens & Atro Rubens & Australia & Yes \\
\hline Atroviolacea Brun Riber & Atro Violacea & Aus & Yes \\
\hline Attica & Attica & Australia & Yes \\
\hline Azapa & NA & --- & --- \\
\hline Barnea 1 & Barnea & Israel & Yes \\
\hline Barnea 2 & Barnea & Israel & Yes \\
\hline Barouni & Barouni & Aus & Yes \\
\hline Belle de Espagne & Sevillano & Spain/Israel & No \\
\hline Benito & NA & 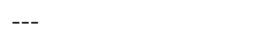 & --- \\
\hline Big Spanish & Sevillano & Spain/Israel & No \\
\hline Black Italian 1 & Black Italian & Aus & No \\
\hline Black Italian 2 & Black Italian & Aus & Yes \\
\hline Blanquette & Blanquetta & Spain & No \\
\hline Blanquette-Early & Blanquetta & Spain & No \\
\hline Blanquette-Late & Blanquetta & Spain & No \\
\hline Boothby's Lucca & Lucca & Aus & Yes \\
\hline Borregiola & Frantoio & Italy2/Spain/Greece & No \\
\hline Bouquettier & Bouquettier & Aus & Yes \\
\hline Bouteillon & Bouteillon & Australia & Yes \\
\hline Buchine & Buchine & Aus & Yes \\
\hline Californian Mission 1 & Mission & United States/Mexico & Yes \\
\hline Californian Mission 2 & Mission & United States/Mexico & No \\
\hline Columella & NA & --- & --- \\
\hline Coratina & Coratina & Spain & Yes \\
\hline Correggiola 1 & Frantoio & Italy2/Spain/Greece & Yes \\
\hline Correggiola 2 & Frantoio & Italy2/Spain/Greece & Yes \\
\hline Cucco & Cucco & Australia & Yes \\
\hline Del Morocco & Del Morocco & Aus & Yes \\
\hline Dr Fiasci & Dr Fiasci & Australia & Yes \\
\hline Emu Flat & Emu Flat & Aus & Yes \\
\hline Frantago & Frantoio & Italy2/Spain/Greece & No \\
\hline Frantoio 1 & Frantoio & Italy2/Spain/Greece & Yes \\
\hline Frantoio 2 & Frantoio & Italy2/Spain/Greece & Yes \\
\hline Frantoja & Frantoio & Italy2/Spain/Greece & Yes \\
\hline FS17 & NA & --- & --- \\
\hline Gaeta & Gaeta & Aus & Yes \\
\hline
\end{tabular}


Table 1. Continued from previous page.

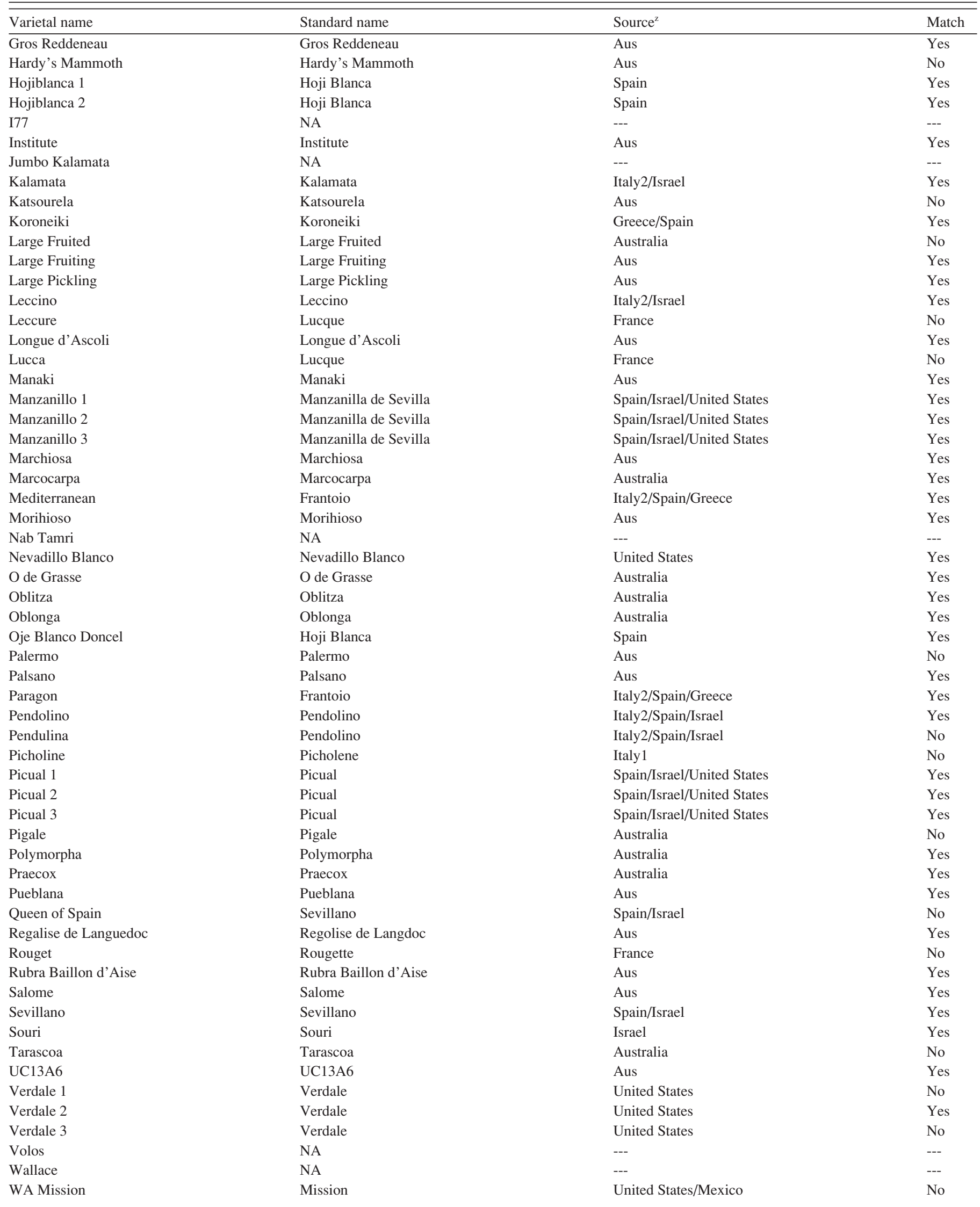

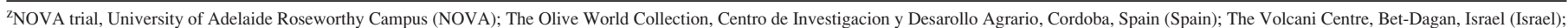

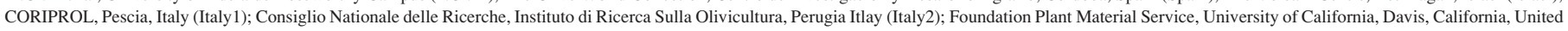

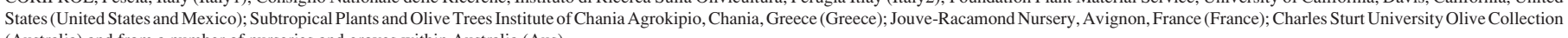
(Australia) and from a number of nurseries and groves within Australia (Aus).

${ }^{\mathrm{y}} \mathrm{NA}=$ not available. 
cultivars in the NOVA collection, the standards that were used for comparison, the source of the standard, and whether or not a positive match was identified. The six 10-mer primers used generated 96 polymorphic bands. In one case, the samples Large Pickling and Verdale 3 were scored as being $100 \%$ genetically similar in the first identification step, however, RAPDs run in adjacent lanes showed that the fingerprints differed between three of the minor bands, and one major band (data not shown). This highlights the importance of running the second comparative gel.

Of the 100 NOVA accessions tested, 58 different genotypes were detected as shown in Fig. 2. A positive match with a standard sample was found for 68 accessions, 46 of the matches being with standards obtained from international collections. Twenty-four cultivars did not match the standard cultivar, and there were no standards available in the database for 10 of the accessions.

GENETIC SIMILARITIES WITHIN THE NOVA CULTIVARS. The presence of synonyms in the NOVA collection is shown in Table 2. These resolved into 14 accessions that produced the same fingerprint as Frantoio (Italy2), five as Verdale Aglandau (France), four as Gordal Sevillana (Spain), three as Verdale (United States), two as Hojiblanca (Spain), two as Koroneiki (Greece), two as Arbequina (Spain), and two as Mission (United States).

Several of the accessions with unusual names, for which there was no standard, have been identified as being known cultivars. For example, Black Italian 1 was genetically similar to Verdale from the United States, Nab Tamri to Gordal Sevillana from Spain, Wallace to Koroneiki from Greece, Big Spanish to Arbequina from Spain, Emu Flat, Mediterranean, and Paragon to

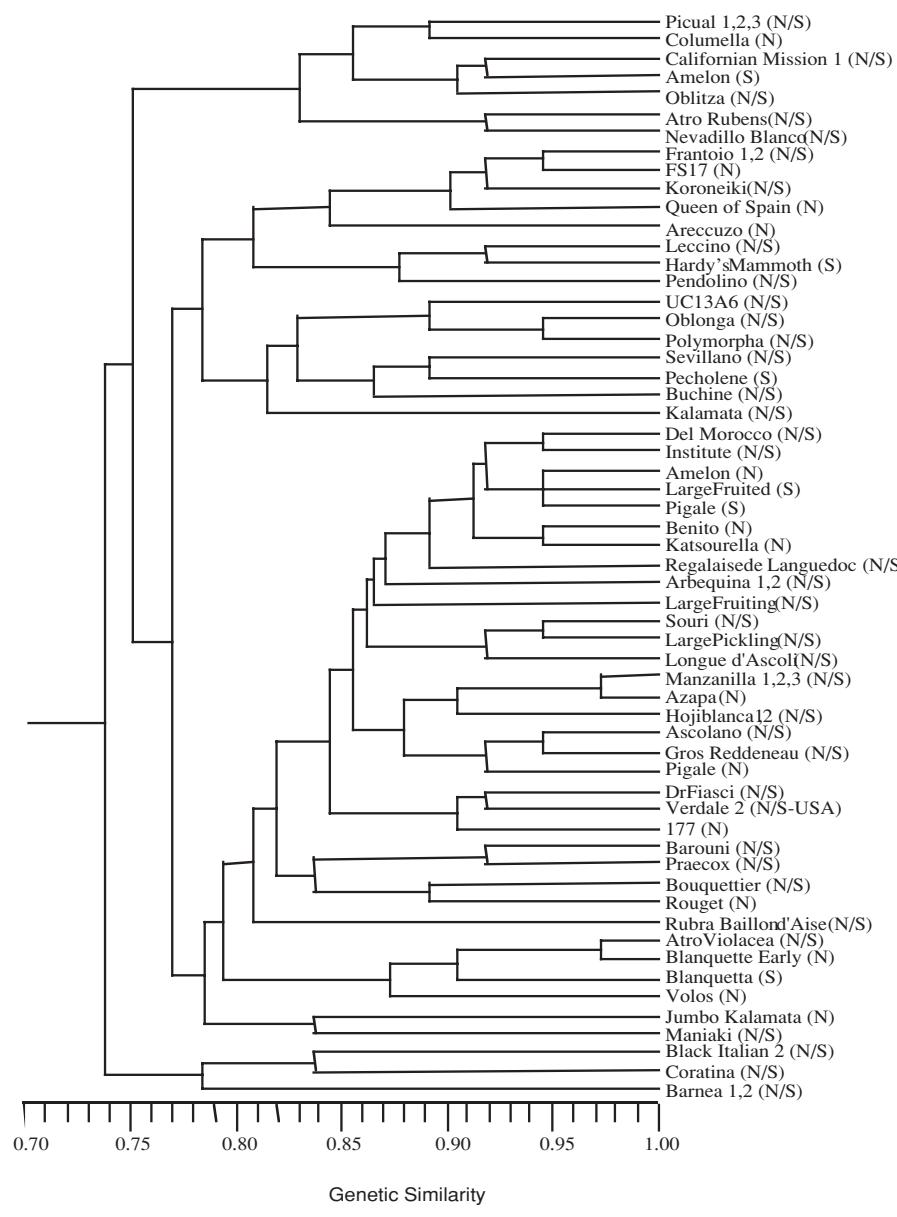

Fig. 2. Dendrogram of accessions tested from the NOVA collection $(\mathrm{N})$ and standards (S) shown in Table 2, that had unique RAPD fingerprints.
Frantoio from Italy, and Hardy's Mammouth to Verdale Aglandau from France.

Seven unidentified groups of individuals that had the same DNA fingerprint were found in the NOVA collection as shown in Table 3. These require comparison to other international standards in order resolve their identities in the future.

BULKED DNA ANALYSIS OF NOVA CULTIVARS. For 11 out of the 100 cultivars planted in the NOVA collection, the RAPD fingerprint of the bulked replicate DNA was not identical to that of the sixth replicate tree. Differences between the bulked samples and individual samples were detected with one or more of the primers used. Figure 3 shows an example of unmatched samples of Hojiblanca 1 that were detected with the primer OPZ11, together

Table 2. Lists of cultivar names with identical DNA fingerprints. The cultivar standards shown in the dendrogram (Fig. 1) are shown in bold type. $\mathrm{N}$ denotes accessions from the NOVA trial and $\mathrm{S}$ denotes the standard cultivar used as indicated in Table 1.

\section{Frantoio (Italy2)}

Belle de Espagne $(\mathrm{N})$

Boothby's Lucca $(\mathrm{N})$

Bouteillon (N/S)

Correggiola $1,2(\mathrm{~N})$

Emu Flat $(\mathrm{N})$

Frantoio 1, $2(\mathrm{~N} / \mathrm{S})$

Frantoja $(\mathrm{N})$

Leccure $(\mathrm{N})$

Lucca $(\mathrm{N})$

Mediterranean $(\mathrm{N})$

Palermo (S)

Palsano (N/S)

Paragon $(\mathrm{N})$

Pueblana (N)

WA Mission (N)

Verdale Aglandau (France)

Gros Reddeneau (N/S)

Hardy's Mammouth (N)

Marchiosa (N/S)

Salome (N/S)

Tarascoa (N)

Gordal Sevillana (Spain)

Cucco (N)

Nab Tamri $(\mathrm{N})$

Sevillano (N/S)

Tarascoa (S)

Verdale (United States)

Black Italian $1(\mathrm{~N})$

Californian Mission 2 (N)

Verdale 2 (N/S)

Hojiblanca (Spain)

Hoji Blanca 1, 2 (N/S)

Oje Blanco Doncel (N)

Koroneiki (Greece)

Koroneiki (N/S)

Wallace $(\mathrm{N})$

Arbequina (Spain)

Arbequina 1,2 (N/S)

Big Spanish (N)

Mission (United States)

Attica (N/S)

Californian Mission 1 (N/S) 
Table 3. Lists of cultivar names with identical DNA fingerprints. Groups 1 through VII contain accessions that had identical fingerprints but did not match any international standard. $\mathrm{N}$ denotes accessions from the NOVA trial and $\mathrm{S}$ denotes the standard cultivar used as indicated in Table 1.

\section{Group I}

Marcocarpa (N/S)

Pendulina (N)

Polymorpha (N/S)

Group II

Blanquette Late $(\mathrm{N})$

Bouquettier (N/S)

Verdale $1(\mathrm{~N})$

Group III

Large Fruited (N)

Large Fruiting (N/S)

Palermo (N)

Group IV

Blanquette $(\mathrm{N})$

Rubra Baillon D'Aise (N/S)

Group V

Borregiola (N)

Gaeta $(\mathrm{N} / \mathrm{S})$

Longue de Ascoli (N/S)

Morihioso (N/S)

Picholine $(\mathrm{N})$

Group VI

Frantago $(\mathrm{N})$

Oblonga $(\mathrm{N} / \mathrm{S})$

Group VII

Del Morocco (N/S)

O'de Grasse (N/S)

with the fingerprints from each of the six trees, showing that accession number three was genetically different.

\section{Discussion}

IDENTIFICATION OF ACCESSIONS IN THE NOVA COLLECTION. In this study, leaf samples were obtained from several international collections and, where possible, the same cultivar was obtained from different collections. Consistency among cultivars from several sources has been established for a number of standards (Fig. 1). Where possible, cultivar accessions obtained from their country of origin were used. These included Picual, Manzanilla de Sevilla, Gordal Sevillana, Blanqueta, Arbequina, and Hojiblanca, from Spain; Frantoio, Leccino, and Pendolino from Italy; Barnea and Souri from Israel; Verdale Aglandau, Rougette, and Lucque from France, Mission from the United States, and Koroneiki from Greece. Other standards were obtained from international sources, but not from the country of origin, such as Kalamata from Israel, Nevadillo Blanco and Ascolano from the United States, and Coratina from Spain.

The number of RAPD markers and primers necessary to distinguish among olive varieties varies between reports. Belaj et al. (2001) found that 18 polymorphic bands from four primers allowed the identification of 51 cultivars from the Germplasm Bank of the Centro de Investigación y Formación Agraria in Cordoba, Spain, and Besnard et al. (2001b) found that 22 bands from three primers distinguished 102 cultivars. In this study, the identity of the accessions in the NOVA collection was initially assessed using 26 polymorphic bands from four primers and then confirmed using 96 polymorphic bands generated by six primers.

Some genetic comparisons of olive cultivars have revealed clusters that equate to fruit size or geographic origin (Belaj et al., 2001; Besnard et al., 2001a; Fabbri et al., 1995; Sanz-Cortés et al., 2001). Although there appear to be four major clusters in the dendrogram (Fig. 2) the cophenetic analysis indicated that clustering could not be distinguished from a random event, and therefore no conclusions can be drawn about the derivation of the cultivars in the NOVA collection.

The presence of both homonyms and synonyms as described by Mekuria et al. (1999) was confirmed. Some cultivars, such as Manzanilla de Sevilla, known as Manzanillo in Australia, produce identical fingerprints regardless of the source, whereas others, such as Verdale and Picholine, are genetically diverse. Homonyms of this type are likely to have arisen from genetically distinct regional varieties that are given the same name, or from populations where propagation is achieved through sexual reproduction.

The largest group of synonyms included 14 accessions that produced the same fingerprint as Frantoio (Tables 2 and 3). Barranco et al. (2000) also found Oblonga to be a synonym of Frantoio, however, the accession named Oblonga from the NOVA trial had an identical DNA fingerprint to another NOVA sample named Frantago and did not match the Frantoio standard from Italy. Many synonyms have previously been reported for Frantoio such as Paragon, Frantoja, and Correggiola (Archer 1999; Mekuria et al., 1999) and 19 different synonyms, including Correggiolo, are listed in the world catalogue of olive varieties (IOOC, 2000).

Of the 58 identified genotypes, 16 were positively identified with international standards, and this group contains the major varieties under cultivation in Australia: Arbequina, Ascolano, Barnea, Coratina, Frantoio, Hojiblanca, Kalamata, Koroneiki,

Fig. 3. RAPD bands generated by OPZ11 for Hojiblanca 1 replicate trees 1 to 6 (lanes 1-6); Hojiblanca standard (Spain) (lane 7); Hojiblanca 1 Bulked DNA (lane 8); negative control (lane 9) and 100 bp Ladder (M).

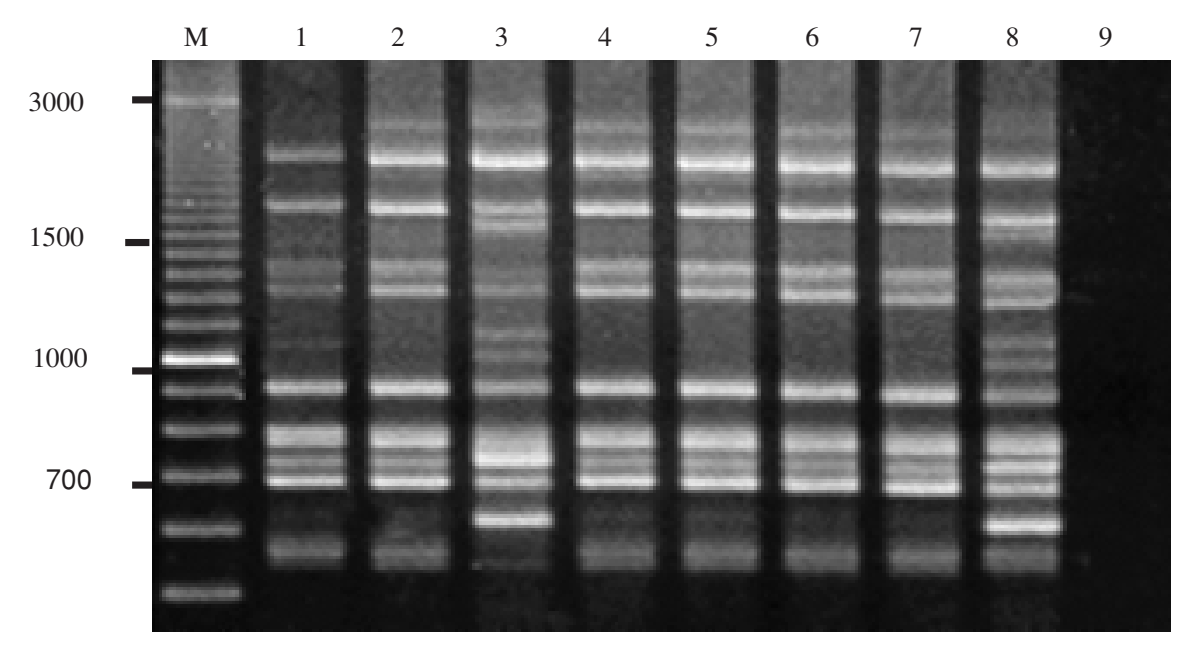


Leccino, Manzanillo, Mission, Nevadillo Blanco, Pendolino, Picual, Sevillano, and Souri.

DEVELOPMENT OF A DATABASE FOR RAPID IDENTIFICATION OF OLIVE ACCESSIONS. In the construction of a dendrogram as the first part of a two-stage process for the rapid identification of accessions, 26 polymorphic bands were produced from four primers. The likelihood of a random individual having a designated DNA fingerprint under these conditions was between $6 \times 10^{-4}$ and $2 \times$ $10^{-8}$. Duplicate DNA fingerprints for Frantoio, Koroneiki, Leccino, Hojiblanca, Picual, Californian Mission, and Nevadillo Blanco were tested in this system and fitted the dendrogram with $>97 \%$ similarity to the first replicate. This dendrogram thus permits new accessions to be identified approximately with speed and efficiency. In the second stage of the process of identification, standards are selected that most closely match the unknown accession, and the PCR products of all samples of DNA are compared on the same gel after a separate amplification with six primers.

Intracultivar variation in olives has been detected using the RAPD technique (Gemas et al., 2000; Mekuria et al., 1999). However, DNA fingerprinting may not be able to distinguish among clonal selections where differences have arisen through somatic mutation and may be manifest at only one or more sites in the genome (Bowers et al., 1993). Small changes in the genetic structure would be difficult to detect using RAPD, or any genotyping method, but may affect the agronomic performance of the tree. The NOVA collection will provide physiological data for each cultivar that will be compared with the DNA fingerprinting results in the future. Cultivars with similar RAPD fingerprints but differing in agronomic qualities could be exploited to find genetic markers for those traits.

The NOVA collection will be an important resource in the future for the assessment of cultivars in a common environment, and will provide the Australian industry with reliable genetic material and provide the basis for quality assurance. The database of olive DNA fingerprints developed in this study is an important tool for identifying cultivars that are being established in groves in Australia.

\section{Literature Cited}

Angiolillo, A., M. Mencuccini, and L. Baldoni. 1999. Olive genetic diversity assessed using amplified fragment length polymorphisms. Theor. Appl. Genet. 98:411-421.

Apostol, B.L., W.C. Black, B.R. Miller, P. Reiter, and B.J. Beaty. 1993. Estimation of the number of full sibling families at an oviposition site using RAPD-PCR markers: Applications to the mosquito Aedes aegypti.
Theor. Appl. Genet. 86:991-1000.

Archer, J. 1999. Paragon = frantoio ... It's as simple as that! Austral. Olive Grower 10:24.

Barranco, D., I. Trujillo, and P. Rallo. 2000. Are 'Oblonga' and 'Frantoio' olives the same cultivar? HortScience 35:1323-1325.

Belaj, A., I. Trujillo, R. De la Rosa, and L. Rallo. 2001. Polymorphism and discrimination capacity of randomly amplified polymorphic markers in an olive germplasm bank. J. Amer. Soc. Hort. Sci. 126:64-71.

Besnard, G., P. Baradat, and A. Bervillé. 2001a. Genetic relationships in the olive (Olea europaea L.) reflect multilocal selection of cultivars. Theor. Appl. Genet. 102:251-258.

Besnard, G., C. Breton, P. Baradat, B. Khadari, and A. Bervillé. 2001b. Cultivar identification in olive based on RAPD markers. J. Amer. Soc. Hort. Sci. 126:663-675.

Bowers, J., E. Bandman, and C. Meredith. 1993. DNA fingerprint characterization of some wine grape cultivars. Amer. J. Enol. Viticult. 44:266-274.

Burr, M. 1998. Varieties, p. 106-116. In: M. Burr (ed.). Australian olives: A guide for growers and producers of virgin oils. $3^{\text {rd }}$ ed. M. Burr, Adelaide.

Collins, G. and R. Symons. 1993. Polymorphisms in grapevine DNA detected by the RAPD PCR technique. Plant Mol. Biol. Rpt. 11:105-112.

Crouse, J. and D. Amorese. 1987. Ethanol precipitation: Ammonium acetate as an alternative to sodium acetate. Focus 9:2-3.

Fabbri, A., J.I. Hormaza, and V.S. Polito. 1995. Random amplified polymorphic DNA analysis of olive (Olea europaea L.) cultivars. J. Amer. Soc. Hort. Sci. 120:538-542.

Gemas, V., M. Rijo-Johansen, R. Tenreiro, and P. Fevereiro. 2000. Interand intra-varietal analysis of three Olea europaea L. cultivars using the RAPD technique. J. Hort. Sci. Biotechnol. 75:312-319.

IOOC. 2000. Italy, p. 137. In: IOOC (ed.). World catalogue of olive varieties. IOOC, Madrid, Spain.

Mekuria, G.T., G.G. Collins, and M. Sedgley. 1999. Genetic variability between different accessions of some common commercial olive cultivars. J. Hort. Sci. Biotechnol. 74:309-314.

Rallo, P., G. Dorado, and A. Martín. 2000. Development of simple sequence repeats (SSRs) in olive tree (Olea europaea L.). Theor. Appl. Genet. 101:984-989.

Sambrook, J., E. Fritsch, and T. Maniatis. 1989. In: Molecular cloning. A laboratory manual. $2^{\text {nd }}$ ed. Cold Spring Harbour Laboratory Press, Cold Spring Harbor, N.Y.

Sanz-Cortés, F., M.L. Badenes, S. Paz, A. Íñiguez, and G. Llácer. 2001. Molecular characterisation of olive cultivars using RAPD markers. J. Amer. Soc. Hort. Sci. 126:7-12.

Sokal, R. and C. Michener. 1958. A statistical method for evaluating systematic relationships. Univ. Kan. Sci. Bul. 38:1409-1438.

Weisman, Z., N. Avidan, S. Lavee, and B. Quebedeaux. 1998. Molecular characterization of common olive varieties in Israel and the West Bank using randomly amplified polymorphic DNA (RAPD) markers. J. Amer. Soc. Hort. Sci. 123:837-841. 